\title{
APLIKASI TEKNOLOGI MICROBIAL FUEL CELL (MFC) UNTUK MENENTUKAN ENERGI LISTRIK SUBSTRAT BATANG SAGU (METROXYLON)
}

\author{
Rahmaniah*, Suriana Binti Ardi, Nurul Fuadi \\ Jurusan Fisika \\ Fakultas Sains dan Teknologi UIN Alauddin Makassar \\ Jl. Sultan Alauddin No. 63, Kabupaten Gowa, Sulawesi Selatan. 92113 \\ *E-mail: rahmaniah.fisika@uin-alauddin.ac.id
}

\begin{abstract}
This study aims to determine how much electrical energy or power density produced from the sago stem substrate using Microbial Fuel Cell $(M F C)$ technology without the addition of electrolytes by adding $\mathrm{KMnO} 4$ and $\mathrm{K} 3 \mathrm{Fe}(\mathrm{CN}) 6$ as an electrolyte solution. From the measurement results, it is obtained that the sago stem substrate sample has electrical potential or power density $(\mathrm{mW} / \mathrm{m} 2)$. The large power density $(\mathrm{mW} / \mathrm{m} 2)$ produced from the sago stem substrate using lactobacillus plantarum bacteria without the addition of an electrolyte solution was obtained at 50,082 $\mathrm{mW} / \mathrm{m} 2$. For samples with the addition of $0.2 \mathrm{M} \mathrm{KMnO4}$ and potassium phosphate buffer with $\mathrm{pH} \mathrm{7,} \mathrm{a} \mathrm{power} \mathrm{density} \mathrm{value} \mathrm{of} \mathrm{91,082} \mathrm{mW} / \mathrm{m} 2$ was obtained and the addition of $\mathrm{K} 3 \mathrm{Fe}$ (CN) $60.2 \mathrm{M}$ and sodium phosphate buffer with $\mathrm{pH} 7$ obtained a power density value of $27,287 \mathrm{~mW} / \mathrm{m} 2$.
\end{abstract}

Keywords: Electrolytes, Lactobacillus plantarum, Microbial Fuel Cell, Power Density, Sago Stems

\section{PENDAHULUAN}

$\mathrm{T}$ lanaman sagu adalah spesies dari genus Metroxylon yang termasuk ke dalam family Palmae. Sagu tumbuh di daerah tropis yang panas dan lembab. Tanaman sagu merupakan tanaman yang memiliki beberapa kandungan yaitu, pada ampas sagu $19.55 \%$ selulosa, kuli batang sagu $56.86 \%$ selulosa, pada kayu $39 \%$ selulosa, pati $24 \%$, gula pentose $20.6 \%$, residu lignin 20.6\%, dan ekstraktif 10\% (Bayu, 2011). Potensi sagu di Indonesia (1.4 juta ha) mencapai lebih dari 50\% potensi pertanian sagu dunia (2.2 juta ha) (Susanto, 2006). Areal penanaman sagu di Indonesia tersebar di banyak daerah seperti Papua, Maluku, Riau, Sulawesi Utara, Sulawesi Selatan, dan Sulawesi Tenggara. Khususnya daerah Sulawesi Selatan menurut data statistik (Direktorat Jenderal Perkebunan, 2018) Tingginya kandungan pati pada sagu, sehingga dapa digunakan sebagai makanan pokok oleh masyarakat, dan kandungan selulosa yang ada pada batang sagu juga tinggi, sehingga dapat digunakan sebagai nutrisi bagi mikroorganisme, serta dapat digunakan pada teknologi microbial fuel cell (MFC) untuk menghasilkan energi ramah lingkungan.

Microbial Fuel Cell (MFC) merupakan perangkat yang menggunakan aktif mikroorganisme (bakteri) sebagai biokatalis di anoda dengan proses anaerob untuk menghasilkan biolistrik. Elektroda diproduksi oleh bakteri oleh substrat yang ditransfer ke anoda dan ke katoda yang dihubungkan dengan bahan konduksi sebagai resistor (Desi, 2017). 
Lactobacillus plantarum adalah bakteri asam laktat dari family Lactobacilliceae dan genus Lactobacillus. Bakteri ini bersifat Gram positif, non motil, dan berukuran 0,6$0,8 \mu \mathrm{m} \times 1,2-6,0 \mu \mathrm{m}$. Besarnya energi listrik pada sistem MFC dipengaruhi oleh laju metabolisme yang dilakukan oleh bakteri. Selain itu, terdapat pula hubungan antara ukuran sel bakteri terhadap besarnya energi listrik yang dihasilkan. Hal ini sesuai dengan penelitian Lee (2010) bahwa bakteri dengan ukuran yang lebih kecil mampu menghasilkan energi listrik lebih besar daripada bakteri yang berukuran besar.

Penelitian menggunakan MFC dengan memanfaatkan limbah telah banyak dilakukan, namun penelitian MFC dengan memanfaatkan substrat masih sangat sedikit, dengan kandungan selulosa yang ada pada batang sagu, sehingga batang sagu dapat digunakan sebagai substrat dan sebagai nutrisi bagi mikroorganisme. Maka dari itu penelitian ini bertujuan untuk mengetahui produksi energi listrik dari substrat batang sagu menggunakan teknologi $\mathrm{MFC}$ dengan menambahkan $\mathrm{KMnO}_{4}$ dan $\mathrm{K}_{3} \mathrm{Fe}(\mathrm{CN})_{6}$ sebagai larutan elektrolit.

\section{METODE PENELITIAN}

Metode yang digunakan pada penelitian ini yaitu melalui beberapa tahapan yaitu antara lain (1) studi literatur, mengambil beberapa referensi dari buku, jurnal dan penelitian sebelumnya untuk mendapatkan teori dan memperkuat pembahasan pada hasil penelitian. (2) Melakukan beberapa preparasi pada alat dan bahan pada ruang laboratorium penelitian dilakukan dan (3) Melakukan analisis berdasarkan data yang dimiliki dari hasil pengukuran arus dan tegangan serta power density.

\section{HASIL DAN PEMBAHASAN}

Microbial Fuel Cell yang digunakan dalam penelitian ini yaitu terdiri dari ruang yaitu anoda dan katoda dengan model terpisah, dimana masing-masing ruang memiliki elektroda grafit yang diambil dari baterai bekas. Kedua ruang ini terpisah dengan menggunakan jembatan garam $\mathrm{KCl}$. Pada penelitian ini dilakukan pengukuran arus dan tegangan pada substrat batang sagu serta untuk mengetahui pengaruh variasi larutan elektrolit yaitu $\mathrm{KMnO}_{4}$ dan $\mathrm{K}_{3} \mathrm{Fe}(\mathrm{CN})_{6}$ konsentrasi $0,2 \mathrm{M}$ pada ruangan katoda dan digunakan juga variasi larutan buffer untuk menjaga kondisi $\mathrm{pH}$ lingkungan Lactobacillus Plantarum pada substrat batang sagu.

Pada proses preparasi mikroorganisme dilakukan dengan menginokulasikan isolat Lactobacillus plantarum ke dalam media nutrient broth. Nutrient broth berfungsi sebagai lingkungan tumbuhnya mikroba Lactobacillus plantarum, hal ini dikarenakan mengandung nutrisi sehingga mikroba dapat tumbuh, kemudian Lactobacillus plantarum diinokulasikan pada substrat batang sagu pada ruang anoda selama 24 jam, hal ini bertujuan agar mikroba dapat beradaptasi terhadap lingkungan barunya. Selama 24 jam bakteri akan melakukan metabolisme menghasilkan energi berupa $\mathrm{CO}_{2}$, proton $\left(\mathrm{H}^{+}\right)$dan elektron pada ruang anoda. Elektron yang dihasilkan dari metabolisme mikroba akan ditransfer ke elektroda melalui membran plasma luar mikroba yang disebut dengan sitokrom, elektron dari anoda ditransfer ke katoda melalui sirkuit eksternal, sedangkan proton yang dihasilkan dari metabolisme akan ditransfer dari anoda ke katoda melalui jembatan garam. Jembatan garam yang digunakan adalah jembatan garam $\mathrm{KCl}$ sehingga proton $\left(\mathrm{H}^{+}\right)$akan dapat terdifusi karena jari-jari $\mathrm{K}^{+}$lebih besar daripada jari-jari $\mathrm{H}^{+}$. Proton dan elektron pada anoda akan digunakan untuk 
mereduksi $\mathrm{Mn}_{7}^{+}$menjadi $\mathrm{Mn}_{4}^{+}$apabila menggunakan larutan elektrolit $\mathrm{KMnO}_{4}$ atau untuk mereduksi $\mathrm{Fe}^{3+}$ menjadi $\mathrm{Fe}^{2+}$ apabila menggunakan larutan elektrolit $\mathrm{K}_{3} \mathrm{Fe}(\mathrm{CN})_{6}$ (Muftiana et al., 2018).

Tabel 1. Hasil Pengukuran Power Density pada Berbagai Variasi Larutan Elektrolit

\begin{tabular}{cc}
\hline Variasi Larutan dan Bahan Buffer & Kerapatan Daya $(\mathrm{mW} / \mathrm{m} 2)$ \\
\hline Tanpa Penambahan & 50.082 \\
$\mathrm{KMnO}_{4}$ dan Buffer Kalium Fosfat & 91.089 \\
$\mathrm{~K}_{3} \mathrm{Fe}(\mathrm{CN})_{6}$ dan Natrium Fosfat & 27.287 \\
\hline
\end{tabular}

Berdasarkan hasil pengukuran hingga mendapatkan nilai arus maksimum dan tegangan maksimum pada setiap reaktor dengan variasi larutan elektrolit dengan bahan buffer kalium fosfat dan natrium fosfat. Maka dapat dilakukan perhitungan power density yang di hasilkan sistem MFC tersebut sebagaimana ditunjukkan pada Tabel 1. Power density adalah daya listrik yang dihasilkan per luas permukaan elektroda. Dari hasil perhitungan berdasarkan variasi larutan elektrolit dan buffer nilai power density yaitu pada substrat batang sagu tanpa larutan elektrolit diperoleh nilai power density sebesar $50.082 \mathrm{~mW} / \mathrm{m}^{2}$ pada penambahan larutan kalium permanganate yaitu sebesar $91.089 \mathrm{~mW} / \mathrm{m}^{2}$ dan nilai power density terendah yaitu pada penambahan larutan kalium ferosianida hasilnya yaitu sebesar $27.287 \mathrm{~mW} / \mathrm{m}^{2}$. Kecilnya nilai power density yang dihasilkan pada penambahan larutan kalium ferosianida. Menurut Lisa Utami et al., (2018) hal ini disebabkan pada proses awal, energi yang dihasilkan dari metabolisme bahan organik sebagian besar digunakan membentuk biofilm. Sel-sel teradsorpsi pada permukaan media, yang kemudian tumbuh dan berkembang menghasilkan extracellular polymeric substances (EPS) untuk membentuk biofilm. Elektroda grafit pada ruang anoda berperan menjadi media lekat pada mikroorganisme untuk membentuk biofilm. Sehingga selain bakteri hidup dan sel bakteri yang mati dapat membentuk lapisan pada permukaan anoda semakin bertambah. Apabila permukaan elektroda sudah dipenuhi oleh biofilm, jumlah elektron yang ditransfer ke elektroda semakin sedikit sehingga terjadi penurunan arus dan tegangan listrik. Menurut Rachmad Ramadhan et al., (2017), power density yang dihasilkan secara rata-rata mengalami penurunan seiring dengan bertambahnya waktu operasi. Hal ini mengakibatkan peningkatan hambatan dalam anoda sehingga menyebabkan penurunan power density.

Berdasarkan hal tersebut hasil dari penelitian yang dilakukan oleh Lisa Utami et al., (2018) yang menggunakan substrat kulit pisang diperoleh nilai power density $\left(\mathrm{mW} / \mathrm{m}^{2}\right)$ sebesar $31,9 \mathrm{~mW} / \mathrm{m}^{2}$ dan penelitian yang dilakukan oleh Mufid Ainun dan Linda (2018) memperoleh hasil power density $\left(\mathrm{mW} / \mathrm{m}^{2}\right)$ pada substrat fruktosa sebesar $10,26 \mathrm{~mW} / \mathrm{m}^{2}$. Dari hasil diperoleh dengan menggunakan substrat batang sagu menghasilkan nilai power density $\left(\mathrm{mW} / \mathrm{m}^{2}\right)$ lebih tinggi dari kedua peneliti terdahulu. Hal ini dikarenakan penggunaan larutan elektrolit $\mathrm{KMnO} 4$ dan larutan buffer kalium fosfat sesuai dengan substrat dan bakteri yang digunakan dalam sistem MFC.

Dengan demikian, dari penjelasan di atas penambahan larutan elektrolit serta buffer berpengaruh dalam mempengaruhi nilai arus dan tegangan serta power density $\left(\mathrm{mW} / \mathrm{m}^{2}\right)$ yang dihasilkan oleh sistem MFC. Dari penelitian ini didapatkan penambahan sesuai larutan elektrolit dengan buffer. Dimana buffer memiliki peran sangat penting dalam menjaga kestabilan $\mathrm{pH}$ lingkungan bakteri sehingga dapat menghasilkan energi maksimum. Penambahan larutan $\mathrm{KMnO}_{4}$ dan kalium fosfat menghasilkan nilai arus maksimum, tegangan maksimum serta power density $\left(\mathrm{mW} / \mathrm{m}^{2}\right)$ berturut-turut $1.3 \mathrm{~mA}$, $102.3 \mathrm{mV}$ dan $91.089 \mathrm{~mW} / \mathrm{m}^{2}$. Pada penambahan $\mathrm{K}_{3} \mathrm{Fe}(\mathrm{CN})_{6}$ dan natrium fosfat 
berturut-turut $0.8 \mathrm{~mA}, 49.8 \mathrm{mV}$ dan power density $\left(\mathrm{mW} / \mathrm{m}^{2}\right) 27.287 \mathrm{~mW} / \mathrm{m}^{2}$. Hal ini disebabkan harga potensial reduksi $\mathrm{KMnO}_{4}$ lebih tinggi yaitu $1.70 \mathrm{~V}$ dibandingkan dengan $\mathrm{K}_{3} \mathrm{Fe}(\mathrm{CN})_{6}$ sebesar $0.36 \mathrm{~V}$.

\section{KESIMPULAN}

Dari hasil pengukuran produksi listrik substrat batang sagu menggunakan bakteri lactobacillus plantarum pada sistem MFC, dapat dikatakan bahwa batang sagu berpotensi produksi listrik. Besar power density $\left(\mathrm{mW} / \mathrm{m}^{2}\right)$ dari substrat batang sagu menggunakan bakteri Lactobacillus plantarum tanpa penambahan larutan elektrolit menghasilkan nilai power density $\left(\mathrm{mW} / \mathrm{m}^{2}\right)$ sebesar $50.082 \mathrm{~mW} / \mathrm{m}^{2}$. Pada penambahan $\mathrm{KMnO}_{4} 0.2 \mathrm{M}$ dan buffer kalium fosfat $\mathrm{pH} 7$ diperoleh nilai power density $\left(\mathrm{mW} / \mathrm{m}^{2}\right)$ sebesar $91.082 \mathrm{~mW} / \mathrm{m}^{2}$ dan penambahan $\mathrm{K}_{3} \mathrm{Fe}(\mathrm{CN})_{6} 0.2 \mathrm{M}$ dan buffer natrium fosfat $\mathrm{pH} 7$ diperoleh nilai power density $\left(\mathrm{mW} / \mathrm{m}^{2}\right)$ sebesar $27.287 \mathrm{~mW} / \mathrm{m}^{2}$.

\section{DAFTAR PUSTAKA}

Agus, J.B. (2011). Modifikasi selulosa ampas sagu dengan polimerisasi pencangkokan dan penautan-silangan. Bogor: IPB

Won, L.S., Jeon, Bo Young Park \& Doo Hyun. (2010). Effect of bacterial cell size on electricity generation in a single-compartemented microbial fuel cell. Biotechnol Lett, 32, 483-487.

Desi, S. Rositari. (2017). Studi pemanfaatan lumpur sebagai sumber alternatif energi dengan menggunakan microbial fuel cells (MFCS). Surabaya: ITSN

Lisa, Utami., et al. (2018). Produksi energi listrik dari limbah kulit pisang (Musa paradisiaca L.) menggunakan teknologi microbial fuel cells dengan permanganat sebagai katolit. al-Kimiya, 5(2), 62-67.

Yogaswara, R.R., et al. (2017). Studi penambahan mikroorganisme pada substrat limbah pome terhadap kinerja microbial fuel cell. Jurnal Teknik Kimia, 12(1). 